\title{
What the Problem with Russell Isn't
}

Abstract: $\quad$ Mark Nelson thinks that Bertrand Russell's well-known criticisms of St. Thomas Aquinas turn on Russell's acceptance of a highly implausible epistemic principle (DAM), and that my previous objection to this claim depends upon the attribution to Russell of an even more implausible Insincerity Objection. While I agree that Russell's criticisms do not turn on the Insincerity Objection, I argue that my previous rejection of the attribution of (DAM) to Russell is welljustified: there is a plausible reading of Russell that requires neither (DAM) nor the Insincerity Objection.

Keywords: Russell, Aquinas, Nelson, Theology, Philosophy of Religion

Word Count: 2843 words

Mark Nelson's 'What the Problem with Aquinas Isn't' (New Blackfriars, 87, 1012, 2006, 605-16) is a response to my 'On the Lack of True Philosophic Spirit in Aquinas' (Philosophy 76, 298, 2001, 615-24), which, in turn, was a response to his 'On the Lack of "True Philosophic Spirit” in Aquinas: Commitment v. Tracking in Philosophic Method’ (Philosophy 76, 296, 2001, 283-96).

In his original paper, Nelson argued that Russell's well-known critique of Aquinasin his History of Western Philosophy (London: Unwin Paperbacks, 1979, at 44454) - is based upon an epistemic principle that is demonstrably wrongheaded and which Russell himself is elsewhere committed to rejecting. In my response, I argued that it is a mistake to suppose that Russell's critique relies upon the epistemic principle that Nelson identifies, and I proposed an alternative interpretation of Russell's remarks. In his new paper, Nelson argues that my alternative interpretation of Russell's remarks is mistaken, and reaffirms all of his original criticisms of Russell. While I think that Nelson misrepresents some parts of my proposed alternative interpretation, I am persuaded by Nelson that I failed to produce a satisfactory reading of Russell in my previous paper. However, I think that it would plainly be a mistake to infer from the failure of my proposed alternative interpretation to the conclusion that Nelson's original interpretation is correct. Rather, we should go back to the text, to see whether there is some other, more plausible interpretation that it will bear.

\section{1}

The text whose interpretation is in dispute runs as follows:

In its general outlines, the philosophy of Aquinas agrees with that of Aristotle, and will be accepted or rejected by a reader in the measure in which he accepted or rejected the philosophy of the Stagyrite. The originality of Aquinas is shown in his adaptation of Aristotle to Christian dogma, with a minimum of alteration. In his day, he was considered a bold innovator; even after his death many of his doctrines were condemned by the universities of Paris and Oxford. He was even more remarkable for systematising than for originality. Even if every one of his doctrines were mistaken, the Summa would remain an imposing intellectual edifice. When he wishes to refute some doctrine, he states it first, often with great 
force, and almost always with an attempt at fairness. The sharpness and clarity with which he distinguishes arguments derived from reason and arguments derived from revelation are admirable. He knows Aristotle well, and understands him thoroughly, which cannot be said of any earlier Catholic philosopher.

These merits, however, seem scarcely sufficient to justify his immense reputation. The appeal to reason is, in a sense, insincere, since the conclusion to be reached is fixed in advance. Take, for example ... [Here, I have excised the text in which Russell gives three examples that he takes to illustrate this point.]

There is little of the true philosophic spirit in Aquinas. He does not, like the Platonic Socrates, set out to follow wherever the argument may lead. He is not engaged in an enquiry, the result of which it is impossible to know in advance. Before he begins to philosophise, he already knows the truth; it is declared in the Catholic faith. If he can find apparently rational arguments for some parts of the faith, so much the better; if he cannot, he need only fall back on revelation. The finding of arguments for a conclusion given in advance is not philosophy, but special pleading. I cannot, therefore, feel that he deserves to be put on a level with the best philosophers either of Greece or of modern times.

Nelson claims, largely on the basis of Russell's use of the words 'does not ... set out to follow wherever the argument may lead', that Russell is committed to an epistemic principle that gives primary importance to the value of arguments. Here is the principle that Nelson attributes to Russell on the basis of these words:

(DAM): Belief B is epistemically permissible for $\mathrm{S}$ at $\mathrm{t}$ iff $\mathrm{B}$ has maximal argument value for $\mathrm{S}$ at $\mathrm{t}$, where:

B has maximal argument value for $\mathrm{S}$ at $\mathrm{t}$ iff no incompatible belief has higher overall argument value for $\mathrm{S}$ at $\mathrm{t}$; and

The overall argument value of $\mathrm{B}$ for $\mathrm{S}$ at $\mathrm{t}=_{\mathrm{df}}$. the balance of the value of the arguments for belief $\mathrm{B}$ over the value of the arguments against $\mathrm{B}$, for $\mathrm{S}$ at $\mathrm{t}$; where

The value of an individual argument for $\mathrm{B}$ for $\mathrm{S}$ at $\mathrm{t}$ is some function of the degree of justification for $\mathrm{S}$ at $\mathrm{t}$ of that argument's premises and the degree of truth-preservingness of the relation between the arguments premises and its conclusion.

Given the numerous objections that can be launched against (DAM), some of which are noted in Nelson's original article, and some more of which are noted in my initial response to Nelson's original article, and given the fact that Russell himself is elsewhere plainly committed to the rejection of (DAM), and given the fact that there is no other evidence that supports the attribution of (DAM) to Russell, there is obviously good reason to ask whether it is plausible to think that Russell's use of the words 'does not ... set out to follow wherever the argument may lead' really does indicate that, in the context of his critical remarks about Aquinas, Russell evinces a commitment to (DAM). 
In light of the claim that Russell goes on to make immediately after he uses these words on which Nelson hangs his critique-'He is not engaged in an enquiry, the result of which it is impossible to know in advance' - it seems to me to be more plausible to suppose that we should not take Russell's use of the word 'argument' at face value, or, at any rate, that we should not take Russell's use of the word 'argument' to have the face value that Nelson wishes to attribute to it. Rather, when Russell says of Aquinas that 'he does not ... set out to follow wherever the argument may lead', it seems to me, we should take Russell to be expressing something in the ballpark of the following observation: Aquinas does not set out on an inquiry concerning things about which he takes himself to be initially ignorant, and then come to beliefs about those things on the basis of the conducted inquiry. The words that Russell then goes on to use help to explain the sense that Russell gives to the claim that Aquinas 'does not ... set out to follow wherever the argument may lead'.

As I have already hinted, it perhaps isn't quite right to say that this interpretation of Russell fails to take his key use of the word 'argument' at face value. There is, after all, an older use of the word 'argument' on which it just means 'the subject matter of discussion'; and there is a current use of the word 'argument' on which it just means 'debate' or 'discussion'. But, given these understandings of the word 'argument', it is natural to narrowly interpret the claim that someone 'fails to follow arguments where they lead' as the claim that the beliefs of that person are not the outcomes or endproducts of debate, discussion, and the like. By contrast, Nelson's interpretation of Russell requires a reading of the word 'argument' on which arguments are something like 'connected series of statements or reasons intended to establish propositions'—or, as Nelson himself says, 'intellectual considerations that could in principle be expressed in terms of premises, conclusions and inferential relations between them' (606). Even setting aside considerations of charity, it seems to me to be plainly wooden to read Russell's words with this interpretation of the word 'argument', and then to use this interpretation to discern the intended sense of Russell's remark.

Of course, it is also worth noting that Russell's remark is not the claim that Aquinas 'fails to follow arguments where the lead'; rather, it is the claim that Aquinas fails to follow the argument where it leads'. That is, Aquinas fails to follow debate, discussion, the project of inquiry, etc. where they lead: he doesn't arrive at his philosophical views on the basis of debate, discussion, inquiry, and so forth. Whether rightly or wrongly, Russell supposes that the business of philosophy is to conduct investigations into questions to which one does not antecedently know the answers, and to arrive at answers to those questions on the basis of those inquiries. If it is true that much —or most, or all —of what Aquinas does is not investigation of questions concerning which, at least prior to investigation, he takes himself not to know the answers, then not only can we understand why Russell supposed that Aquinas is not amongst the very best of philosophers, we can also see that, given Russell's view about the business of philosophy, he might have had good reasons for holding that Aquinas is not amongst the very best of philosophers.

In my initial response to Nelson, I argued that: 
The core of Russell's complaint against Aquinas is that there is a sense in which the Thomistic project is 'insincere': the arguments which are advanced do not coincide with the real reasons why beliefs are maintained. ... The core crime is to engage in activity which brings with it the danger that one will be all too ready to reach out to embrace bad arguments. ... Russell's complaint against Aquinas is that it is a perversion of genuine philosophical enquiry to fail to use one's real reasons when arguing for conclusions which one accepts: it is this failure which constitutes the epistemic crime of 'failing to follow the argument where it leads', and which is a kind of 'special pleading'. (619-621)

On the basis of these remarks, Nelson attributes the following argument to me:

1. Whenever $\mathrm{S}$ believes $\mathrm{P}$ for a reason, there will always be some reason, $\mathrm{R}$, that is S's real or main reason for believing $\mathrm{P}$.

2. Whenever $S$ believes $P$ and gives philosophical argument for $P$, then the premises of that argument should express R; anything else would be insincere.

3. At many points, Aquinas believes some thesis $\mathrm{P}$, for some reason, $\mathrm{R}$, but gives an argument for $\mathrm{P}$, the premises of which do not express $\mathrm{R}$.

4. Therefore, at many points, Aquinas' arguments are insincere.

While I think that there are grounds for objecting to the claim that it is precisely this argument to which I evinced commitment-for example, there is nothing in what I wrote that commits me to the first premise, since I consistently referred to 'real' or 'main' reasons in the plural-I agree that the last sentence in the quotation above requires a commitment to something like the argument that Nelson identifies, and I also agree with Nelson that the argument that he sets out is a bad argument.

That's not to say that there is nothing that is right in the arguments that I gave. Russell does write: 'The appeal to reason is, in a sense, insincere, since the conclusion to be reached is fixed in advance'. Moreover, it seems to me to be plausible to suppose that Russell did think that, because Aquinas was not engaged in investigation of questions concerning which, prior to investigation, he took himself not to know the answers, there was a higher risk that Aquinas would be ready to reach out to embrace bad arguments. However, I concede that it is just wrong to think that failure to follow arguments where they lead is a matter of failing to use one's real reasons when one argues for conclusion that one accepts. Rather, as I have already argued, failure to follow arguments where they lead is properly understood to be a matter of failing to come to philosophical beliefs as the outcomes of properly conducted philosophical inquiries, i.e. inquiries that one undertakes from an initial state in which one does not suppose that one already knows the answers to the questions to be investigated in the inquiry.

At the end of his new article, Nelson writes as follows:

In their preface to their Principia, Whitehead and Russell claim that: ... the chief reason of any theory on the principles of mathematics must always be inductive, i.e., it must lie in the fact that the theory in question enables us to deduce ordinary mathematics. In mathematics, the greatest 
degree of self-evidence is usually not be found quite at the beginning, but at some later point; hence the early deductions, until they reach this point, give reasons rather for believing the premises because true consequences follow from them, then for believing the consequences because they follow from the premises.

This may be as true in philosophy as it is in mathematics, at least on Aquinas' view. I suspect that part of the reason Russell does not see this is because he thinks that Aquinas cannot have knowledge of substantive truths of religion on the basis of revelation, and so he must await the outcome of philosophical argumentation. Indeed, this is suggested in Russell's claim that Aquinas 'is not engaged in an enquiry, the result of which it is impossible to know in advance'. This, more than the Insincerity Objection, lies at the bottom of Russell's complaint against Aquinas: Russell thinks these results cannot be known in advance; Aquinas thinks they can. (616)

Much of this seems right to me. In Russell's view, the greatest philosophers investigate questions concerning which they initially take themselves not to know the answers, and then arrive at answers to these questions on the basis of philosophical inquiry. Russell holds that, since Aquinas doesn't investigate questions concerning which he initially takes himself not to know the answers, only to arrive at answers to those questions on the basis of philosophical inquiry, Aquinas is not among the greatest philosophers. This is the basis of Russell's 'complaint' against Aquinas; and, moreover - contra Nelson-it is also the content of Russell's claim that Aquinas fails to follow the argument where it leads.

Even granting the claims made in the previous paragraph, there is still the question whether Russell is right to say that Aquinas fails to follow the argument where it leads. True enough, Aquinas takes himself to know many things on the basis of revelation. But, to the extent that Aquinas was animated by questions about the extent to which the writings of Aristotle could be reconciled with Christian revelation, it is not obvious that we should agree that Aquinas failed to follow the argument where it led. At the very least, Russell would surely need to concede that it is not universally true that Aquinas fails to follow the argument where it leads: on a range of questions, this is exactly what Aquinas does do. Perhaps, however, Russell might reply that, these considerations notwithstanding, we should not judge that Aquinas is one of the greatest philosophers because so much of what he does is 'special pleading', i.e. so much of what he does is construction of arguments for conclusions derived not from engagement in the project of philosophical inquiry, but rather from the teachings of the Church.

Nor will it do to argue, as Nelson does, that Russell cannot make this charge against Aquinas without incriminating himself, at least insofar as his prosecution of the project of Principia Mathematica is concerned. The key point here is that, in the relevant sense, the derivations in Principia Mathematica are not intended to be arguments for their conclusions: they are not intended to persuade anyone of the truth of their conclusions. However, as Nelson himself notes, the Summa Contra Gentiles is constructed as a set of arguments that are intended to persuade non-Christians to adopt the Christian faith. It is not in the least bit plausible to view the Summa Contra Gentiles - or the Summa Theologica — as an axiomatisation of Christian faith; nor is it in the least bit plausible to view Principia Mathematica as a remedy for passing 
doubts, or as an exhibition of the interconnectedness of mathematical beliefs, or as a deepening of one's understanding of the particular beliefs in question, or as something that raises one's degree of justification for the particular beliefs. One obtains no deeper understanding of the proposition that $2+2=4$, nor an increased degree of justification for believing that $2+2=4$, from a reading of Principia Mathematica.

Since my purpose here is not to defend Russell's verdict on Aquinas, I don't propose to pursue this line of inquiry. I have no interest in defending any particular line on the question where Aquinas stands in the pantheon of philosophy. What I do have a particular interest in is the fairness and correctness of readings of Russell's writings. Thus, while I certainly allow that Russell's verdict on Aquinas is not obviously correct, I think that it is important to affirm — contra Nelson — that Russell's verdict is neither 'breathtakingly supercilious and unfair' nor, more importantly, the product of an idiotic epistemology. 